$\begin{array}{rr}\text { FIT(PPATOLOGI } & \text { Volume } 10, \text { Nomor 5, Oktober } 2014 \\ \text { IN DONESIA } & \text { Halaman } 145-152 \\ \text { ISSN: } 0215-7950 & \text { DOI: } 10.14692 / \text { jif. } 10.5 .145\end{array}$

\title{
Interaksi antara Bakteri Endofit dan Bakteri Perakaran Pemacu Pertumbuhan Tanaman dalam Menekan Penyakit Layu Bakteri pada Tomat
}

\section{Interaction between Endophytic Bacteria and Plant Growth-Promoting Rhizobacteria to Control Bacterial Wilt Disease on Tomato}

\author{
Abdjad Asih Nawangsih*, Fitri Fatma Wardani \\ Institut Pertanian Bogor, Bogor 16680
}

\begin{abstract}
ABSTRAK
Salah satu faktor yang mempengaruhi produksi tomat ialah adanya penyakit layu bakteri yang disebabkan oleh Ralstonia solanacearum. Salah satu alternatif pengendalian yang ramah lingkungan untuk mengelola penyakit ini ialah dengan memanfaatkan agens biokontrol. Aplikasi bakteri endofit Staphylococcus epidermidis BC4 dan rizobacteria pemacu pertumbuhan tanaman (RPPT) (Pseudomonas fluorescens RH4003 dan Bacillus subtilis AB89) diharapkan menjadi alternatif tersebut. Penelitian ini bertujuan mengevaluasi interaksi antara bakteri endofit dan RPPT dalam menekan perkembangan penyakit layu bakteri dan pemacuan pertumbuhan tomat. Perlakuan bakteri yang dapat memacu pertambahan tinggi dan bobot kering tanaman ialah kombinasi antara $75 \%$ S. epidermidis BC4 dengan $25 \%$ P. fluorescens RH4003. Perlakuan yang dapat menekan insidensi penyakit paling tinggi ialah perlakuan $P$. fluorescens RH4003 yang diaplikasikan secara tunggal. Indeks penekanan penyakit oleh $S$. epidermidis BC4 dan P. fluorescens RH4003 secara tunggal berturut-turut mencapai 41.18 dan 45.88\%. Interaksi antara bakteri endofit dan kedua bakteri perakaran pemacu pertumbuhan tanaman bersifat antagonis.
\end{abstract}

Kata kunci: Bacillus subtilis, bakteri endofit, PGPR, Pseudomonas fluorescens, Staphylococcus epidermidis

\begin{abstract}
One of the factors affected production of tomato is the incidence of bacterial wilt disease caused by Ralstonia solanacearum. An alternative control to manage the disease which is environmentally friendly is the use of biocontrol agents. Application of endophytic bacteria (Staphylococcus epidermidis BC4) and plant growth promoting rhizobacteria (Pseudomonas fluorescens RH4003 and Bacillus subtilis AB89) as biocontrol of tomato bacterial wilt was expected to be an alternative method. The objective of this study is to evaluate the interaction among endophytic bacteria and PGPR to suppress the development of bacterial wilt disease ( $R$. solanacearum) and promoting the growth of tomato. Bacterial treatment which caused the highest suppression on disease incidence was single application of P. fluorescens RH4003. Disease index caused by S. epidermidis BC4 and P. fluorescens RH4003 applied individually was up to 41.18 dan $45.88 \%$, respectively. Interaction between the endophytic bacteria and both of the PGPRs were antagonistic.
\end{abstract}

Key words: Bacillus subtilis, endophytic bacteria, PGPR, Pseudomonas fluorescens, Staphylococcus epidermidis

*Alamat Penulis Korespondensi: Departemen Proteksi Tanaman, Fakultas Pertanian, Institut Pertanian Bogor, Kampus Darmaga, Jalan Kamper, Bogor 16680.

Tel: 0251-8629364, Faks: 02518629362, Surel: asnawangsih@yahoo.com 


\section{PENDAHULUAN}

Produksi tomat di Indonesia pada tahun 2000-2010 relatif mengalami kenaikan meskipun masih ada kendala di lapangan (BPS 2012). Salah satu kendala produksi tomat adalah penyakit layu bakteri yang disebabkan oleh Ralstonia solanacearum. Di daerah tropika penyakit layu bakteri dapat menyebabkan kerugian yang cukup besar, bahkan dapat menggagalkan panen (Alvarez et al. 2010).

Varietas tahan dapat mengendalikan penyakit layu bakteri dengan baik, tetapi pengendalian ini tidak dapat digunakan dalam jangka panjang. Varietas tahan akan memberikan tekanan biologi kepada patogen sehingga akan memunculkan galur baru yang lebih virulen (Almoneafy et al. 2012). Pengendalian menggunakan bahan kimia merupakan salah satu penyebab kerusakan lingkungan dan terjadinya ketahanan bakteri (EPPO 2011). Oleh karena itu, diperlukan pengendalian yang tepat.

Agens biokontrol adalah makhluk hidup yang berperan sebagai penekan perkembangan patogen dengan cara menghambat pertumbuhan dan perkembangan patogen tersebut. Kemampuan suatu agens biokontrol dapat ditingkatkan dengan mengombinasikan 2 atau lebih agens biokontrol (Guetsky et al. 2002). Persyaratan agar kombinasi 2 agens biokontrol atau lebih dapat bekerja secara optimal ialah mereka dapat bekerja pada tempat yang berbeda, misalnya pada rizosfer atau sisa-sisa bahan organik; memiliki mekanisme pengendalian yang berbeda, misalnya kompetisi dan antibiosis; memerlukan substrat yang berbeda, misalnya lendir tanaman untuk bakteri dan cendawan atau eksudat akar untuk bakteri kelompok pseudomonas; dan hidup kompatibel dengan lingkungan tanah serta perubahan yang terjadi karena peningkatan cara bercocok tanam (Roberts et al. 2005; Mishra et al. 2011).

Agens biokontrol yang dapat digunakan sebagai alternatif pengendalian dalam rangka mewujudkan sistem pertanian yang berkelanjutan adalah bakteri endofit dan rizobakteria pemacu pertumbuhan tanaman (RPPT) (Sutariati et al. 2006; Nawangsih et al. 2011). Bakteri endofit adalah bakteri yang mengolonisasi jaringan tanaman sehat tanpa menyebabkan penyakit pada inangnya, sedangkan RPPT adalah kelompok bakteri menguntungkan yang agresif mengolonisasi rizosfer. Bakteri Pseudomonas fluorescens RH4003 (Nawangsih et al. 2007) dan Bacillus subtilis AB89 adalah RPPT yang telah berhasil diisolasi dari perakaran tomat. Aplikasi di lapangan mampu menekan perkembangan penyakit layu bakteri.

Penelitian ini bertujuan menguji interaksi antara bakteri endofit dan RPPT dalam meningkatkan pertumbuhan tomat dan menekan perkembangan penyakit layu bakteri.

\section{BAHAN DAN METODE}

\section{Penyiapan Tanaman Uji}

Benih yang digunakan ialah tomat varietas Arthaloka. Varietas ini dipilih karena banyak digunakan oleh petani. Benih disemai pada nampan pot berukuran $25 \mathrm{~cm} \times 35 \mathrm{~cm}$. Pada setiap nampan ditanami 15 sampai 20 benih. Medium tanam yang digunakan dalam persemaian ialah tanah steril dan pupuk kandang dengan perbandingan 1:1. Bibit dipelihara selama 3 minggu.

\section{Penyiapan Suspensi Bakteri Endofit dan Rizobakteria Pemacu Pertumbuhan Tanaman}

Bakteri endofit dan RPPT yang digunakan dalam penelitian merupakan koleksi Laboratorium Bakteriologi Tumbuhan, Fakultas Pertanian, Institut Pertanian Bogor. Bakteri endofit yang digunakan ialah Staphylococcus epidermidis dan RPPT ialah P. fluorescens RH4003 (P1) dan B. subtilis AB89 (B12) yang diisolasi dari perakaran tomat (Nawangsih 2007).

Medium yang digunakan untuk pembuatan suspensi agens biokontrol ialah Nutrient Broth (NB). Suspensi S. epidermidis BC4, B. subtilis AB89, dan P. fluorescens RH4003 yang digunakan untuk perlakuan memiliki kerapatan $10^{9}-10^{10} \mathrm{cfu} \mathrm{mL}^{-1}$. 


\section{Uji Penekanan Insidensi Penyakit pada Plot Percobaan}

Medium tanam yang digunakan dalam uji penekanan insidensi penyakit ialah tanah steril, pupuk kandang, dan tanah yang telah terinfestasi $R$. solanacearum. Tanah steril dan pupuk kandang dengan perbandingan 1:1 dicampur secara merata. Kantong plastik yang digunakan untuk pot uji berukuran $30 \mathrm{~cm} \times$ $30 \mathrm{~cm}$. Pot dibagi menjadi 3 bagian, dengan ketebalan masing-masing $\pm 6 \mathrm{~cm}$. Bagian bawah diisi dengan campuran tanah steril dan pupuk kandang, bagian tengah diisi dengan tanah yang terinfestasi $R$. solanacearum, dan yang paling atas diisi kembali dengan campuran tanah steril dan pupuk kandang.

Bibit yang telah direndam dalam kombinasi suspensi bakteri selama sehari ditanam pada medium tanam. Masing-masing bibit disiram dengan $50 \mathrm{~mL}$ kombinasi suspensi yang sama. Pemeliharaan dilakukan dengan menyiram tanaman 2 hari sekali dengan air atau sesuai kebutuhan. Pemasangan ajir dilakukan pada waktu tanaman tomat berumur 2 minggu setelah pindah tanam. Jumlah perlakuan pada uji ini adalah 10 perlakuan (Tabel 1) dengan 5 tanaman per perlakuan dan ditanam pada 3 blok yang berbeda sehingga didapatkan 50 tanaman per blok.

Tanaman uji disiram dengan kombinasi RPPT dan bakteri endofit 2 kali, yaitu sehari sebelum pindah tanam dan pada hari saat pindah tanam. Untuk penyiraman bibit sebelum maupun setelah pindah tanam diperlukan volume kombinasi $50 \mathrm{~mL}$. Misal untuk proporsi kombinasi 25:75 maka disiapkan $12.5 \mathrm{~mL}$ bakteri endofit dan $37.5 \mathrm{~mL}$ RPPT. Untuk perbandingan 0:0 (kontrol) kombinasi hanya berisi $50 \mathrm{~mL}$ air untuk penyiraman bibit dan $50 \mathrm{~mL}$ air untuk penyiraman bibit setelah pindah tanam.

Pengamatan terhadap insidensi penyakit (IP) dilakukan setiap minggu. Insidensi penyakit dihitung dengan rumus (Cooke 1998):

$$
\mathrm{IP}=\mathrm{n} / \mathrm{N} \times 100 \% \text {, dengan }
$$

IP, insidensi penyakit; $\mathrm{n}$, jumlah tanaman yang terserang patogen; $\mathrm{N}$, jumlah tanaman yang diamati.
Setelah insidensi penyakit diketahui kemudian dihitung nilai area under disease progress curve (AUDPC) dengan rumus Van der Plank (Cooke 1998) sebagai berikut:

$$
\text { AUDPC }=\sum_{i}^{n=1}\left(\frac{y_{i}+y_{i+1}}{2}\right) \times\left(t_{i+1}-t_{i}\right) \text {,dengan }
$$

$y$, persentase insidensi penyakit; $t$, hari.

Nilai AUDPC yang telah diketahui kemudian digunakan untuk menghitung indeks penekanan penyakit. Indeks penekanan penyakit ialah suatu angka yang dapat menyatakan tingkat keefektifan pengendalian suatu agens biokontrol terhadap patogen. Indeks penekanan penyakit dihitung dengan rumus:

$\underset{\text { penyakit }}{\text { Indeks penekanan }}=\frac{\text { Dic-Dib }}{\text { Dic }} \times 100 \%$, dengan

Dic, AUDPC pada kontrol; Dib, AUDPC pada perlakuan agens biokontrol.

Agens biokontrol yang digunakan dalam penelitian merupakan 2 agens biokontrol yang dikombinasikan dengan berbagai proporsi. Untuk mengetahui tingkat sinergisme antara 2 agens biokontrol tersebut digunakan rumus Abbott's (Guetsky et al. 2002):

$$
\mathrm{E}_{(\exp )}-\mathrm{a}+\mathrm{b}-\left(\frac{\mathrm{a} \times \mathrm{b}}{100}\right) \text { dan } \mathrm{SF}=\frac{\mathrm{E}_{(\text {obs })}}{\mathrm{E}_{(\exp )}}
$$

SF, Synergy Factor; a, keefektifan pengendalian oleh agens biokontrol I; b, keefektifan pengendalian oleh agens biokontrol II; $\mathrm{E}_{(\exp )}$, keefektifan pengendalian dugaan oleh campuran agens biokontrol; $\mathrm{E}_{(\mathrm{obs})}$, keefektifan pengendalian oleh campuran berdasarkan hasil pengamatan.

Hubungan interaksi kedua agens biokontrol ditentukan dengan ketentuan bila $\mathrm{SF}=1$ maka interaksi antaragens biokontrol bersifat aditif, bila $\mathrm{SF}<1$ maka interaksi antaragens biokontrol bersifat antagonis, bila $\mathrm{SF}>1$ maka interaksi antaragens biokontrol bersifat sinergis (Guetsky et al. 2002).

\section{Uji Pemacuan Pertumbuhan}

Medium tanam yang digunakan adalah tanah steril dan pupuk kandang dengan perbandingan 1:1. Medium tanam dimasukkan ke dalam kantong plastik dengan ukuran 
$30 \mathrm{~cm} \times 30 \mathrm{~cm}$ dan kemudian ditanami bibit tomat yang telah disiram dengan suspensi kombinasi bakteri endofit dan RPPT sehari sebelum pindah tanam. Kemudian tanaman disiram kembali dengan kombinasi yang sama pada saat pindah tanam.

Penelitian disusun dalam rancangan acak kelompok dengan ulangan sebanyak 3 kali sebagai kelompok. Perlakuan yang diberikan sebanyak 10 perlakuan dan jumlah tanaman yang digunakan ialah 5 tanaman per perlakuan. Pengamatan terhadap tinggi tanaman dilakukan setiap minggu hingga 42 hari setelah tanam (HST) dan bobot kering tanaman diukur pada 42 HST (Tabel 1).

Data tinggi tanaman yang diperoleh kemudian digunakan dalam penghitungan nilai area under height of plant growth curve (AUHPGC). Nilai AUHPGC dihitung menggunakan rumus Van der Plank (Cooke 1998) sebagai berikut:

AUHPGC $=\sum_{i}^{n=1}\left(\frac{y_{i}+y_{i+1}}{2}\right) \times\left(t_{i+1}-t_{i}\right)$,dengan $\mathrm{y}$, laju pertambahan tinggi tanaman; t, hari.

\section{HASIL}

\section{Indisensi Penyakit Layu Bakteri}

Insidensi penyakit layu bakteri pada minggu ke-1 dan ke-2 paling tinggi terjadi pada tanaman yang diberi perlakuan $\mathrm{B}_{0} \mathrm{P}_{100}$ dengan insidensi sebesar $13.3 \%$ dan yang paling rendah terjadi pada perlakuan $\mathrm{B}_{25} \mathrm{P}_{75}$, $\mathrm{B}_{100} \mathrm{P}_{0}, \mathrm{~B}_{0} \mathrm{~A}_{100}$, dan $\mathrm{B}_{50} \mathrm{~A}_{50}$ dengan insidensi penyakit layu masing-masing sebesar $0.0 \%$. Pada minggu ke-7 insidensi penyakit layu bakteri paling rendah, yaitu sebesar $40.0 \%$ terjadi pada perlakuan $\mathrm{B}_{0} \mathrm{P}_{100}$ sedangkan yang tertinggi terjadi pada tanaman yang diberi perlakuan $\mathrm{B}_{75} \mathrm{~A}_{25}$, yaitu sebesar $100 \%$. Insidensi penyakit pada minggu ke-7 pada kontrol sebesar 65.0\% (Gambar 1).

Nilai AUDPC tertinggi, yaitu 560 unit terjadi pada tanaman dengan perlakuan kombinasi $S$. epidermidis BC4 75\% dan $B$. subtilis $\mathrm{AB} 8925 \%\left(\mathrm{~B}_{75} \mathrm{~A}_{25}\right)$ sedangkan nilai AUDPC terendah yaitu 220 unit terjadi pada tanaman dengan perlakuan $P$. fluorescens RH4003 yang diaplikasikan secara tunggal $\left(\mathrm{B}_{0} \mathrm{P}_{100}\right)$. Nilai AUDPC pada kontrol sebesar 340 unit (Tabel 2). Hal ini menunjukkan bahwa aplikasi P. fluorescens RH4003 secara tunggal dapat menekan tingkat insidensi penyakit layu bakteri lebih baik dibandingkan dengan perlakuan kombinasi.

\section{Jenis Hubungan Rizobakteria Pemacu Pertumbuhan Tanaman dan Bakteri Endofit \\ Perlakuan tunggal $S$. epidermidis BC4 $\left(\mathrm{B}_{100} \mathrm{P}_{0}\right)$ dan P. fluorescens RH4003 $\left(\mathrm{B}_{0} \mathrm{P}_{100}\right)$ memberikan indeks penekanan penyakit lebih besar dibandingkan dengan perlakuan lain,}

Tabel 1 Kode perlakuan dan proporsi suspensi bakteri dalam perlakuan pada uji penekanan penyakit

\begin{tabular}{lccc}
\hline & \multicolumn{3}{c}{ Proporsi suspensi bakteri dalam perlakuan (\%) } \\
\cline { 2 - 4 } Kode perlakuan & $\begin{array}{c}\text { Staphylococcus } \\
\text { epidermidis } \mathrm{BC} 4\end{array}$ & $\begin{array}{c}\text { Bacillus subtilis } \\
\text { (B) }\end{array}$ & $\begin{array}{c}\text { Pseudomonas fluorescens } \\
\text { RH4003 }\end{array}$ \\
\hline Kontrol & 0 & 0 & $(\mathrm{P})$ \\
$\mathrm{B}_{0} \mathrm{P}_{100}$ & 0 & 0 & 0 \\
$\mathrm{~B}_{25} \mathrm{P}_{75}$ & 25 & 0 & 100 \\
$\mathrm{~B}_{50} \mathrm{P}_{50}$ & 50 & 0 & 75 \\
$\mathrm{~B}_{75} \mathrm{P}_{25}$ & 75 & 0 & 50 \\
$\mathrm{~B}_{100} \mathrm{P}_{0}$ & 100 & 0 & 25 \\
$\mathrm{~B}_{0} \mathrm{~A}_{100}$ & 0 & 100 & 0 \\
$\mathrm{~B}_{25} \mathrm{~A}_{75}$ & 25 & 75 & 0 \\
$\mathrm{~B}_{50} \mathrm{~A}_{50}$ & 50 & 50 & 0 \\
$\mathrm{~B}_{75} \mathrm{~A}_{25}$ & 75 & 25 & 0 \\
\hline
\end{tabular}




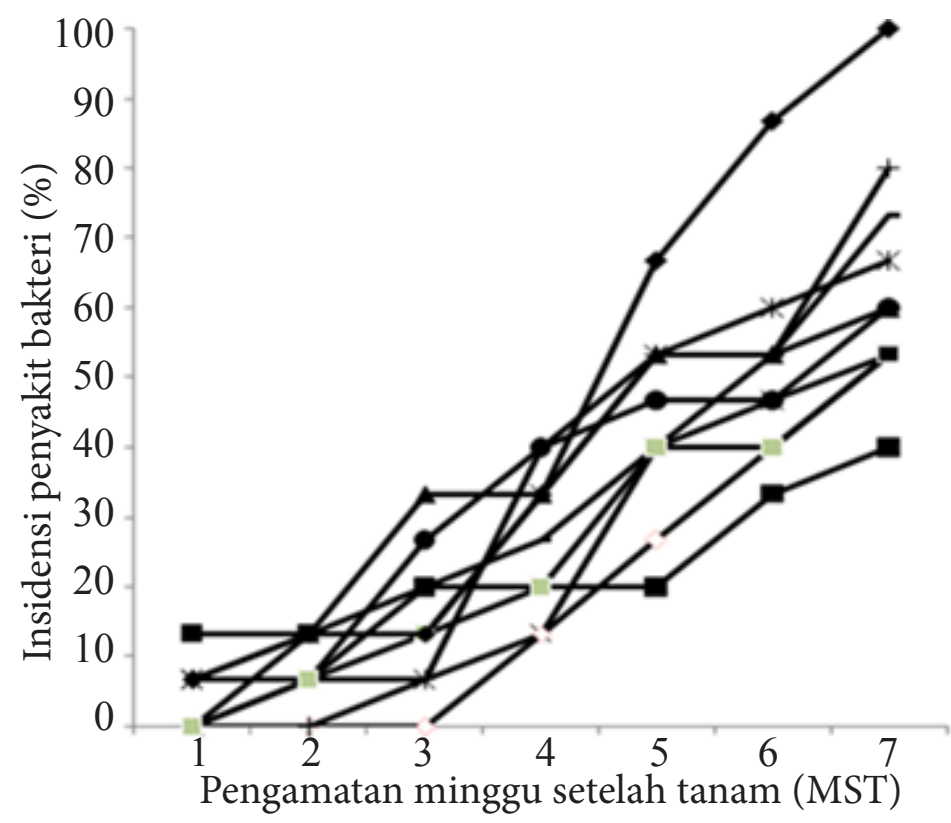

Gambar 1 Indisensi penyakit layu bakteri pada berbagai perlakuan bakteri endofit dan RPPT dari minggu ke-1 sampai minggu ke-7. $\rightarrow$, kontrol; $-\mathbf{-}, \mathrm{B}_{0} \mathrm{P}_{100} ;-, \mathrm{B}_{25} \mathrm{P}_{75} ; \leftarrow, \mathrm{B}_{50} \mathrm{P}_{50} ;-$, $\mathrm{B}_{75} \mathrm{P}_{25} ;=-\mathrm{B}_{100} \mathrm{P}_{0} ;+\mathrm{B}_{0} \mathrm{~A}_{100} ;-\mathrm{B}_{25} \mathrm{~A}_{75} ;--\mathrm{B}_{50} \mathrm{~A}_{50} ; \rightarrow, \mathrm{B}_{75} \mathrm{~A}_{25}$

K, kontrol; A, Bacillus subtilis AB89; B, Staphylococcus epidermidis BC4; P, Pseudomonas fluorescens RH4003.

Tabel 2 Nilai area under disease progress curve (AUDPC) pada berbagai perlakuan bakteri endofit dan rizobakteria pemacu pertumbuhan tanaman di rumah kaca

\begin{tabular}{lc}
\hline Perlakuan $^{\mathrm{a}}$ & \multicolumn{1}{c}{ AUDPC (unit) } \\
\hline Kontrol & $340 \pm 36.64 \mathrm{ab}$ \\
$\mathrm{B}_{0} \mathrm{P}_{100}$ & $220 \pm 124.89 \mathrm{~b}$ \\
$\mathrm{~B}_{25} \mathrm{P}_{75}$ & $340 \pm 227.15 \mathrm{ab}$ \\
$\mathrm{B}_{50} \mathrm{P}_{50}$ & $300 \pm 103.92 \mathrm{~b}$ \\
$\mathrm{~B}_{75} \mathrm{P}_{25}$ & $380 \pm 124.89 \mathrm{ab}$ \\
$\mathrm{B}_{100} \mathrm{P}_{0}$ & $280 \pm 34.64 \mathrm{~b}$ \\
$\mathrm{~B}_{0} \mathrm{~A}_{100}$ & $400 \pm 124.89 \mathrm{ab}$ \\
$\mathrm{B}_{25} \mathrm{~A}_{75}$ & $380 \pm 173.21 \mathrm{ab}$ \\
$\mathrm{B}_{50} \mathrm{~A}_{50}$ & $280 \pm 173.21 \mathrm{~b}$ \\
$\mathrm{~B}_{75} \mathrm{~A}_{25}$ & $560 \pm 36.64 \mathrm{a}$ \\
\hline a A, B. subtilis AB89; B, S. epidermidis $\mathrm{BC} 4 ; \mathrm{P}$, P. \\
fuorescens RH4003 \\
bangka yang diikuti huruf yang sama pada kolom yang \\
sama tidak berbeda nyata berdasarkan uji Duncan pada \\
taraf 5\%.
\end{tabular}

yaitu masing-masing sebesar $41.18 \%$ dan $45.88 \%$. Perlakuan kombinasi yang memberikan penekanan terhadap perkembangan penyakit ialah perlakuan $\mathrm{B}_{50} \mathrm{~B}_{50}$ dan $\mathrm{B}_{50} \mathrm{P}_{50}$. Kedua perlakuan tersebut dapat menekan insidensi penyakit layu bakteri masing-masing sebesar $17.65 \%$ dan $11.76 \%$ (Tabel 3).
Berdasarkan nilai SF, hubungan antara S. epidermidis BC4 dengan B. subtilis AB89 maupun hubungan antara $S$. epidermidis BC4 dengan P. fluorescens RH4003 bersifat antagonis (Tabel 3).

\section{Pertambahan Tinggi dan Bobot Kering Tanaman}

Perlakuan $\mathrm{B}_{0} \mathrm{P}_{100}$ (P. fluorescens $\mathrm{RH} 4003$ secara tunggal), $\mathrm{B}_{75} \mathrm{P}_{25}$ dan $\mathrm{B}_{100} \mathrm{P}_{0} \quad(S$. epidermidis $\mathrm{BC} 4$ secara tunggal) menghasilkan nilai AUHPGC lebih besar dibandingkan dengan nilai AUHPGC pada kontrol yang menunjukkan bahwa ketiga perlakuan tersebut dapat meningkatkan pertambahan tinggi tanaman. Nilai AUHPGC pada perlakuan $\mathrm{B}_{0} \mathrm{P}_{100}$ sebesar 461.65 unit, pada perlakuan $\mathrm{B}_{75} \mathrm{P}_{25}$ sebesar 494.93 unit dan $\mathrm{B}_{100} \mathrm{P}_{0}$ sebesar 459.95 unit sedangkan pada kontrol sebesar 442.40 unit (Tabel 4).

\section{PEMBAHASAN}

Berdasarkan hasil penelitian ini terlihat bahwa kedua jenis agens biokontrol apabila dikombinasikan kurang dapat menekan indisensi penyakit maupun memacu 
Tabel 3 Indeks penekanan penyakit, nilai sinergy factor (SF) dan jenis hubungan antara rizobakteria pemacu pertumbuhan tanaman dan bakteri endofit dari perlakuan kombinasi berdasarkan nilai area under disease progress curve (AUDPC)

\begin{tabular}{lcccc}
\hline Perlakuan & $\begin{array}{c}\text { Indeks penekanan } \\
\text { penyakit }(\%)^{\mathrm{a}}\end{array}$ & $\mathrm{E}_{(\mathrm{obs})} \mathrm{b}^{\mathrm{b}}$ & $\begin{array}{c}\text { Sinergy factor } \\
(\mathrm{SF})\end{array}$ & Jenis hubungan \\
\hline $\mathrm{B}_{0} \mathrm{~A}_{100} \mathrm{c}$ & -17.65 & & & \\
$\mathrm{~B}_{100} \mathrm{P}_{0}$ & 41.18 & & & \\
$\mathrm{~B}_{0} \mathrm{P}_{100}$ & 45.88 & 30.79 & -0.38 & Antagonis \\
$\mathrm{B}_{25} \mathrm{~A}_{75}$ & -11.76 & 30.79 & 0.57 & Antagonis \\
$\mathrm{B}_{50} \mathrm{~A}_{50}$ & 17.65 & 30.79 & -2.10 & Antagonis \\
$\mathrm{B}_{75} \mathrm{~A}_{25}$ & -64.71 & 68.17 & 0.00 & Antagonis \\
$\mathrm{B}_{25} \mathrm{P}_{75}$ & 0.00 & 68.17 & 0.17 & Antagonis \\
$\mathrm{B}_{50} \mathrm{P}_{50}$ & 11.76 & 68.17 & -0.17 & Antagonis \\
$\mathrm{B}_{75} \mathrm{P}_{25}$ & -11.76 & & & \\
\hline
\end{tabular}

${ }^{a}$ Relatif dibandingkan dengan kontrol

${ }^{\mathrm{b}}$ Keefektifan pengendalian dugaan oleh kombinasi RPPT dan bakteri endofit

${ }^{\mathrm{C}} \mathrm{A}$, B. subtilis AB89; B, S. epidermidis BC4; P, P. fluorescens RH4003

Tabel 4 Nilai area under height of plant growth curve (AUHPGC) dan rerata bobot kering tanaman berumur 6 minggu setelah tanam pada berbagai perlakuan bakteri endofit dan rizobakteria pemacu pertumbuhan tanaman

\begin{tabular}{llc}
\hline Perlakuan $^{\mathrm{a}}$ & Nilai AUHPGC $($ unit) & Bobot kering per tanaman $^{\mathrm{b}}(\mathrm{g})$ \\
\hline Kontrol & $442.40 \pm 40.13 \mathrm{abc}$ & $6.75 \pm 1.76 \mathrm{ab}$ \\
$\mathrm{B}_{0} \mathrm{P}_{100}$ & $461.65 \pm 70.28 \mathrm{ab}$ & $6.14 \pm 1.66 \mathrm{ab}$ \\
$\mathrm{B}_{25} \mathrm{P}_{75}$ & $413.58 \pm 64.88 \mathrm{bcd}$ & $6.43 \pm 2.09 \mathrm{ab}$ \\
$\mathrm{B}_{50} \mathrm{P}_{50}$ & $393.40 \pm 42.13 \mathrm{bcd}$ & $6.30 \pm 2.63 \mathrm{ab}$ \\
$\mathrm{B}_{75} \mathrm{P}_{25}$ & $494.93 \pm 48.87 \mathrm{a}$ & $7.87 \pm 1.57 \mathrm{a}$ \\
$\mathrm{B}_{100} \mathrm{P}_{0}$ & $459.95 \pm 31.77 \mathrm{ab}$ & $6.69 \pm 0.52 \mathrm{ab}$ \\
$\mathrm{B}_{0} \mathrm{~A}_{100}$ & $413.63 \pm 19.94 \mathrm{bcd}$ & $6.04 \pm 0.32 \mathrm{ab}$ \\
$\mathrm{B}_{25} \mathrm{~A}_{75}$ & $383.43 \pm 17.13 \mathrm{~cd}$ & $5.62 \pm 0.82 \mathrm{ab}$ \\
$\mathrm{B}_{50} \mathrm{~A}_{50}$ & $414.05 \pm 50.00 \mathrm{bcd}$ & $6.02 \pm 0.84 \mathrm{ab}$ \\
$\mathrm{B}_{75} \mathrm{~A}_{25}$ & $362.55 \pm 67.46 \mathrm{~d}$ & $4.68 \pm 1.68 \mathrm{~b}$
\end{tabular}

${ }^{\mathrm{a}} \mathrm{A}$, B. subtilis $\mathrm{AB} 89 ; \mathrm{B}$, S. epidermidis $\mathrm{BC} 4 ; \mathrm{P}$, P. fluorescens $\mathrm{RH} 4003$

${ }^{\mathrm{b}}$ Angka yang diikuti huruf yang sama pada kolom yang sama tidak berbeda nyata berdasarkan uji Duncan pada taraf $5 \%$.

pertambahan tinggi tanaman dibandingkan dengan apabila diaplikasikan secara tunggal. Hal tersebut berbeda dengan laporan Handini dan Nawangsih (2014). Mereka melaporkan P. fluorescens RH4003 kurang dapat meningkatkan pertumbuhan tanaman tomat dibandingkan dengan kombinasi $S$. epidermidis $\mathrm{BC} 4$.

P. fluorescens adalah bakteri ubiquitos dan biasanya ditemukan pada permukaan daun dan akar. P. fluorescens dapat menghasilkan pigmen pioverdin dan atau fenazin pada medium
King's B dan akan berpendar di bawah sinar near ultra violet. Selain itu, $P$. fluorescens juga dapat menekan populasi patogen dengan cara melindungi akar dari serangan patogen dengan mengolonisasi akar, menghasilkan senyawa kimia berupa antimikrob dan antibiotik, dan melakukan kompetisi dalam penyerapan $\mathrm{Fe}^{2+}$ (Couillerot et al. 2009).

B. subtilis adalah bakteri Gram positif, bersifat saprob dan dapat membentuk spora (Nihorimbere et al. 2010). Sama halnya dengan P. fluorescens, B. subtilis juga merupakan 
bakteri yang mengolonisasi akar tanaman. $B$. subtilis AB89 dapat memacu pertumbuhan tanaman (Handini dan Nawangsih 2014).

Hasil penelitian menunjukkan bahwa perlakuan kombinasi kurang memberikan hasil yang baik terhadap pertumbuhan tanaman. Berdasarkan nilai SF, ketiga jenis bakteri tersebut bersifat saling antagonis. Hal ini dapat terjadi karena adanya kompetisi antara 2 bakteri yang diaplikasikan. Kompetisi ruang dan nutrisi dapat terjadi sehingga memengaruhi penghambatan patogen. Nutrisi yang kurang pada medium tanam akan memperparah kompetisi antardua agens biokontrol (Nurbaya et al. 2011). Sifat antagonis ini dapat ditanggulangi dengan waktu aplikasi yang berbeda antara RPPT dan bakteri endofit atau yang biasa disebut dengan rotasi aplikasi agens biokontrol (Janousek et al. 2009).

Selain pertambahan tinggi tanaman, bobot kering tanaman juga digunakan sebagai peubah dalam uji pemacuan pertumbuhan. Bobot kering tertinggi dihasilkan oleh tanaman dengan perlakuan $\mathrm{B}_{75} \mathrm{P}_{25}$, sedangkan bobot kering terendah dihasilkan oleh tanaman dengan perlakuan $\mathrm{B}_{75} \mathrm{~A}_{25}$. Bobot kering tersebut lebih rendah bila dibandingkan dengan kontrol.

Berdasarkan hasil tersebut dapat disimpulkan bahwa aplikasi agens biokontrol secara kombinasi tidak memberikan penekanan insidensi penyakit yang lebih baik dibandingkan dengan perlakuan tunggal karena hubungan antara RPPT dan bakteri endofit yang digunakan bersifat antagonis. Indeks penekanan penyakit oleh $S$. epidermidis $\mathrm{BC} 4$ dan P. fluorescens $\mathrm{RH} 4003$ yang diaplikasikan secara tunggal berturut-turut mencapai $41.18 \%$ dan $45.88 \%$.

\section{UCAPAN TERIMAKASIH}

Penelitian ini didanai sebagian dari Program Penelitian Desentralisasi (Hibah Bersaing) dengan judul: Upaya pemanfaatan bakteri endofit dan PGPR untuk mengendalikan penyakit layu bakteri oleh Ralstonia solanacearum pada tomat (Tahun
III) atas biaya DIPA IPB berdasarkan kontrak Nomor: 01/I3.24.4/SPP/PHB/2011.

\section{DAFTAR PUSTAKA}

Almoneafy AA, Xie GL, Tian WX, Xu LH, Zhang GQ, Ibrahim M. 2012. Characterization and evaluation of Bacillus isolates for their potential plant growth and biocontrol activity against tomato bacterial wilt. Afr J Biotechnol. 11(28):7193-7201. DOI: http://dx.doi. org/10.5897/AJB11.2963.

Alvarez B, Biosca EG, Lopez MM. 2010. On the life of Ralstonia solanacearum, a destructive bacterial plant pathogen. Di dalam: Vilas AM, editor. Current Research, Technology and Education Topics in Applied Microbiology and Microbial Biotechnology. Valencia (SP): Formatex. hlm 267-279.

[BPS] Badan Pusat Statistik. 2012. Produksi tomat pada tahun 2000-2009. Jakarta (ID): BPS.

Cooke BM. 1998. Disease assessment and yield loss. Di dalam: Jones DG, editor. The Epidomiology of Plant Diseases.Ed ke-2. London (UK): Kluwer. hlm 42-72.

Couillerot O, Combaret CP, Mellado JC, Loccoz YM. 2009. Pseudomonas fluorescens and closely-related fluorescent pseudomonads as biocontrol agents of soil-borne phytopathogens. Lett Appl Microbiol. 48(2009):505-512. DOI: $\quad$ http://dx.doi.org/10.1111/j.1472765X.2009.02566.X.

[EPPO] European and MediterraneanPlant Protection Organization. 2011. Quarantine pest: data sheet of quarantine pest Ralstonia solanacearum. European Union. http:// www.eppo.int/QUARANTINE/bacteria/ Ralstonia_solanacearumPSDMSO_ ds.pdf. [diakses 3 Mei 2011].

Guetsky R, Shtienberg D, Elad Y, Fischer E, Dinoor A. 2001. Combining biocontrol agents to reduce the variability of biocontrol agent. Phytopathology. 91(7):621627. DOI: http://dx.doi.org/10.1094/ PHYTO.2001.91.7.621. 
Guetsky R, Shtienberg D, Elad Y, Fischer E, Dinoor A. 2002. Improving biological control by combining biocontrol agents each with several mechanisms of disease suppression. Phytopathology. 92(9):976985. DOI: http://dx.doi.org/10.1094/ PHYTO.2002.92.9.976.

Handini ZVT, Nawangsih AA. 2014. Keefektifan bakteri endofit dan bakteri perakaran pemacu pertumbuhan tanaman dalam menekan penyakit layu bakteri pada Tomat. J Fitopatol Indones. 10(2):6167. DOI: http://dx.doi.org/10.14692/ jifi.10.2.61.

Janousek CN, Lorber JD, Gubler WD. 2009. Combination and rotation of bacterial antagonists to control powdery mildew on pumpkin. JPDP. 116(6):260-262.

Mishra DS, Gupta AK, Prajapati CR, Singh US. 2011. Combination of fungal and bacterial antagonists for management of root and stem rot disease of soybean. Pakistan J Bot. 43(5):2569-2574.

Nawangsih AA, Damayanti I, Wiyono S, Kartika JG. 2011. Selection and Characterization of endophytic bacteria as biological control agents of tomato bacteria wilt disease. Hayati. 18(1):66-70. DOI: http://dx.doi.org/10.4308/hjb.18.2.66.

Nawangsih AA, Kanehasi K, Tjahjono B, Sinaga MS, Suwanto A, Wattimena GA, Negishi H, Suyama K. 2007. Antibacterial activity of Pseudomonas fluorescens RH4003 against bacterial wilt of tomato. J ISSAAS. 13(2):30-39.

Nihorimbere V, Ongena M, Cawoy $H$, Brostaux Y, Kakana P, Jourdan E, Thonart
P. 2010. Beneficial effect of Bacillus subtilis on field-grown tomato in Burundi: reduction of local Fusarium disease and growth promotion. Afr J Microbiol Res. 4(11):1135-1142.

Nurbaya, Rahim MD, Kuswinanti T, Baharuddin. 2011. Sinergisme antar isolat bakteri antagonis dalam mengendalikan penyakit layu bakteri (R.solanacearum) pada sistem budidaya aeroponik tanaman kentang. Seminar dan Pertemuan Tahunan XXI PEI, PFI Komda Sulawesi Selatan dan Dinas Perkebunan Pemerintah Provinsi Sulawesi Selatan; 2011 Jun 7, Makassar (ID). PFI PEI Komda Sulsel. Tersedia pada: http://www.peipfi-komdasulsel.org/ wp-content/uploads/2012/03/3-Nurbayadkk-Penggunaan-formulasi-sinbat.pdf.

Roberts DP, Lohrke SM, Meyer SLF, Buyer JS, Bowers JH, Baker CJ, Li wei, Souza JT, Lewis JA, Chung S. 2005. Biocontrol agents apllied individually and in combination for suppression of soilborne disease of cucumber. Crop Prot. 24(2005):141-155. DOI: http://dx.doi. org/10.1016/j.cropro.2004.07.004.

Ryan RP, Germaine K, Franks A, Ryan DJ, Dowling DN. 2007. Bacterial endophytes: recent developments and applications. FEMS Microbiol Lett. 278:1-9. DOI:http://dx.doi.org/10.1111/j.15746968.2007.00918.x.

Sutariati GAK, Widodo, Sudarsono, Ilyas S. 2006. Pengaruh Perlakuan Rizo-bakteri pemacu pertumbuhan tanaman terhadap viabilitas benih serta pertumbuhan bibit tanaman cabai. Bul Agron. 34(1):46-54. 